$\begin{array}{ll}\text { Salaries in Research and Development } \\ \text { Belgium } & £ 5,400-£ 7,5 \jmath 0 \\ \text { Britain } & £ 4,5 \jmath 0-£ 7,500 \\ \text { France } & £ 5,800-£ 8,300 \\ \text { Germany } & £ 5,000-£ 7,000 \\ \text { Italy } & £ 6,250-£ 10,400 \\ \text { Netherlands } & £ 5,400-£ 7,500 \\ \text { United States } & £ 7,500-£ 11,250\end{array}$

the scientist seems highly valued, and Italian salaries in general are more generous than the rest of Europe. In France, the marketing man docs best. It is perhaps surprising that each of the countries examined shows a similar trend, with marketing men at one end of the salary scale and personnel men at the other. In between are sandwiched executives in finance, production and research and development, in descending order. Salaries at the top end of the range in Europe are broadly comparable with those at the bottom end of the range in the United States.

The rate of growth of salaries in Europe has been rapid, according to the consultants, and one reason why British executives come out badly from the survey is because they have failed to increase their salaries as rapidly as their European counterparts. While salaries in France have gone up by 78 per cent, and in Belgium by 75 per cent in the past eight years, British executives now earn only 43 per cent more. West Germany, which boasted the highest executive salaries eight years ago, has shown only a 50 per cent growth.

\section{Making Booms Acceptable}

More research is needed on the physiological and psychological reactions to sonic booms, but it should be possible to build a supersonic jet that generates a boom of "acceptable characteristics". This is the general conclusion of a recent study on the human response to sonic boom carried out by a subcommittee of the Committee on SST-Sonic Boom under Professor Raymond A. Bauer of the Harvard School of Business Administration. The committee was set up by the National Academy of Sciences and the National Research Council at the request of the President in 1964.

Evidence from field studies indicates that there are no direct physiological effects-such as damage to hearing-from booms up to $100 \mathrm{lb}$./sq. ft, many times above any likely level, but that indirect physiological damage may occur from surprise at even "moderate" levels of noise. More studies of individual and community response must be made, however, whenever test conditions--such as airforce tests of supersonic jets over populated areas-are available. While the costs of such community studies-involving as they do a large number of interviewers and teams of competent researchers-may seem to be high, the report points out that the costs are slight compared with the large sums that would otherwise be spent later on SST redesign and development.

Those who are hoping for noiseless supersonic planes or restricted flights for SSTs are likely to be disappointed. The report's pragmatic approach is to look for the highest human tolerance level, in subgroups and in communities at large, and to leave engineers with the problem of keeping the boom within this level over heavily populated areas. The report points out that the level of individual discomfort is not necessarily the only criterion for defining an "intolerable" condition, for complaints are not always directly related to the level of physical discomfort. Studies must look into this phenomenon and try to determine which groups are more affected, or more actively protest, as well as considering such questions as whether people exposed to booms "become more or less tolerant over the course of time, whether booms in a noisy community are the 'straw that breaks the camel's back' or are merely one of many minor irritants".

The only consolation for many of us is Professor Bauer's point that the current commercial SST will need at least 100 miles after takeoff to reach a speed sufficient to generate a sonic boom, thereby avoiding the largest metropolitan areas on takeoff and landing.

\section{Tropical Techniques}

THE increasing number of enquiries from outside Britain is a sign that there is a world-wide and growing demand for the help of the Tropical Products Institute. According to the annual report of the institute, in 1967 there were 1,012 enquiries from 104 countries as well as international agencies, compared with 852 enquiries from 87 countries in 1966. Late in 1966 there was a change in emphasis of the research at the institute. It was decided to devote more resources to food science and technology, and 1967 was in effect the first year of the new policy. One of the most promising of the new projects is an attempt to increase the protein content of cassava or tapioca by fermentation. Cassava is a source of food starch and industrial starch and, in the normal processing of the erop, it is fermented and leached to remove toxic glycosides, but the resulting tapioca is deficient in protein. By using selected fungi and adding minerals, the protein content can be raised from $0 \cdot 1$ per cent in the original flour to 4 per cent and, if successful, further research could lead to conversion of tapioca into protein food on an industrial scale.

Apart from food research, the institute has followed up a chance observation made in Ethiopia which may lead to the development of new molluscicides active against the snails which carry bilharzia. People living at Adwa on the Assam River in Ethiopia use the fruit of the endod, which is rich in saponins, as natural soap. Dead snails and fish were noticed at the washing holes and laboratory tests showed that extracts of the endod fruit in tap water are potent molluscicides. At this stage the institute was asked for help in the identification and isolation of the active compounds. This work is still in progress, but the saponins have been identified as the molluscicides and there is every hope that the endod and a number of other tropical plants will become new sources on a commercial scale of molluscicides.

Another of the institute's projects sets out to make bricks from rice. The idea is that rice hulls, which are otherwise hard to dispose of, are available in large quantities and contain very few cement "poisons", might be used to replace gravel to produce lightweight concrete. Experiments have produced a way of making rice hull bricks strong enough to build one and two story houses. The institute is now starting to design simple presses and collapsible moulds for the large scale production of the bricks on building sites. 